\title{
UNESCOn neljäs aikuiskasvatuksen maailmankonferenssi
}

\begin{abstract}
Alkio, Olavi. 1985. Unescon neljäs aikuiskasvatuksen maailmankonferenssi v. 1985. Aikuiskasvatus 5, 2, 60-66. - Artikkeli on lyhennelmä Suomen valtuuskunnan puheenjohtajan laatimasta virallisesta matkakertomuksesta. Artikkelissa esitellään valmistautumista Unescon 4. kansainväliseen aikuiskasvatuskonferenssiin, itse konferenssin työskentelyä sekä konferenssissa käsiteltyjä asioita.
\end{abstract}

UNESCOn IV aikuiskasvatuksen maailmankonferenssi järjestettiin Pariisissa UNESCOn päämajassa 19.-29.3.1985. Suomen valtuuskuntaan kuuluivat puheenjohtajana opetusneuvos Olavi Alkio opetusministeriöstä sekä jäseninä kulttuurisihteeri Eeva Hippula opetusministeriöstä, rehtori Kari Kinnunen Työväen Akatemiasta, suunnittelupäällikkö Liekki Lehtisalo opetusministeriöstä, lähetystöneuvos Iivo Salmi ulkoasiainministeriöstä (1. viikko), lehtori Singa Sandelin Helsingin yliopistosta, toimistopäällikkö Kaisa Savolainen ammattikasvatushallituksesta ja ulkoasiainsihteeri Ulla Väistö-Melleri ulkoasiainministeriöstä (2. viikko).

\section{Ennakkovalmistelut}

Ennakkojärjestelyt lähtivät hyvissä ajoin liikkeelle. Tieto tulossa olevasta konferenssista saatiin varhain ja vuonna 1982 UNESCO lähetti jäsenmaille laajan kyselyn aikuiskasvatuksen kehityksestä edellisen, Tokiossa pidetyn maailmankonferenssin ja Nairobissa vuonna 1976 pidetyn yleiskokouksen jälkeen. Suomikin laati kyselyyn n. 60-sivuisen vastauksen ("Adult Education in Finland. Reply by Finland to the questions concerning the development of adult education since the adoption in 1976 of the Unesco Recommendation on the Development of Adult Education'). 
Saksan liittotasavallassa Hampurissa järjestettiin Euroopan alueen valmistava kokous vuoden 1983 alkupuolella. Tämän jälkeen ei valmisteluista kuulunutkaan juuri mitään. Syyskuussa 1984 UNESCO lähetti kutsun, josta kävi ilmi konferenssin aika ja paikka sekä alustava esityslista ja menettelytapaohjeet.

Lopullista esityslistaa tai työjärjestystä ei saatu etukäteen. Niiden puuttuminen hankaloitti kokoukseen valmistumista. Kutsun saapumisen jälkeen Suomen Unesco-toimikunta asetti konferenssia valmistelemaan työryhmän, jonka puheenjohtajana toimi toimistopäällikkö Kaisa Savolainen ammattikasvatushallituksesta. Työryhmä ryhtyi laatimaan ajantasalla olevaa esitystä Suomen aikuiskoulutuksesta (Report on Adult Education in Finland 1985. Publications of the Finnish National Commission for Unesco n:o 31) ja suunnittelemaan kansallista valmistelevaa aikuiskoulutuskokousta, joka pidettiin 1.2.1985 (n. 40 osallistujaa).

Suomen valtuuskunta maailmankonferenssiin nimitettiin 13.2.1985. Sen jälkeen aloitettiin kiireelliset valmistelut em. raportin viimeistelemiseksi ja jäsenten kokouspuheenvuorojen muotoilemiseksi.

Lähinnä kansallisen valmistelevan seminaarin pohjalta valtuuskunta valmisteli myös päätöslauselmaehdotuksen, jossa korostettiin kansainvälisyyskasvatuksen merkitystä ja viitattiin esimerkkinä kansainvälisen rauhankasvatusverkoston toimintaan.

\section{Konferenssin tekniset järjestelyt}

Konferenssi pidettiin UNESCOn päämajassa, joten sillä oli käytettävissään järjestön koko tekninen koneisto.

Suomen valtuuskunnalle oli erinomainen apu ulkoasiainministeriön UNESCOssa olevasta toimistosta ja sen toimistotyöntekijästä.

\section{Konferenssin järjestäytyminen}

Konferenssin avasi ja päätti UNESCOn pääsihteeri M'Bow. Puheenjohtajaksi valittiin Zimbabwen opetusministeri D.B. Mutumbuka, joka hoitikin ajoittain vaikean tehtävän taidolla.

Konferenssille valittiin 14 varapuheenjohtajaa seuraavien maiden valtuuskunnista: Algeria, Argentiina, Ecuador, Iso-Britannia, Intia, Jemen, Jordania, Jugoslavia, Kiinan kansantasavalta, Kongo, Neuvostoliitto, Nigeria, Puola ja Turkki.
Ranskan Jean-Marie Gouault valittiin pääraportoijaksi.

Konferenssi päätti asettaa kaksi komissiota. Ensimmäisen puheenjohtajana toimi Venetsuelan Luis Contreras ja toisen puheenjohtajana Sri Lankan Nissanka Wijeyeratne. Suomi onnistui saamaan ensimmäisen komissicn (yhdeksi kuudesta) varapuheenjohtajaksi Kaisa Savolaisen.

Jonkin verran erimielisyyttä oli luonnosteluryhmän (drafting group) asettamismahdollisuudesta ja sen asemasta. Niinpä se nimettiin vasta kuudentena kokouspäivänä. Se osoittautui kuitenkin täysin välttämättömäksi kokouksen lopputuloksen kannalta.

\section{Yleisvaikutelma}

USAn UNESCOa kohtaan esittämä kritiikki, sen eroaminen järjestöstä ja tästäkin aiheutunut taloudellinen kriisi vaikuttivat konferenssin ilmapiiriin. Sitä kuvailivat monet useissa UNESCOn erityiskokouksissa mukana olleet erääksi yleispolitiikan eniten värittämäksi.

USA ei ollut mukana kokouksessa, mutta länsimaiden ns. informaatioryhmän ensimmäisessä kokouksessa kuultiin USAn hallituksen asettaman tarkkailuryhmän puheenjohtajaa (Leonard Marks), joka totesi, että ne vaatimukset, jotka USA on asettanut ehdoksi takaisinpaluulleen, eivät näytä toteutuvan. Suurin kritiikki kohdistui järjestön management and administration -alueelle. Ainakin tämän puheenvuoron perusteella näytti siltä, että tarkkailuryhmän vuoden lopussa USAn hallitukselle jättämä raportti tulee olemaan kielteinen jäsenyyden uudistamiseen nähden.

Myös muiden länsimaiden puheenvuoroissa esitettiin ajoittain voimakastakin kritiikkiä UNESCOn toimia kohtaan. Voimakkainta kritiikki oli Englannin ja Japanin taholta, jotka olivat jo ennen kokousta uhanneet erota UNESCOsta.

Monet katsoivatkin näiden valmistelevan eroaan. Sen sijaan Saksan liittotasavallan ja Ranskan kannanotot olivat edellisiä maltillisempia, joskin joiltakin osin hyvinkin kriittisiä.

Vastapainoksi muut maat pyrkivät ilmeisesti välttämään kaikkia aiheita, jotka saattaisivat aiheuttaa mielipide-erojen kärjistymistä jäsenvaltioiden välillä. Niinpä esimerkiksi Neuvostoliitto oli valmis vetämään pois ja muokkaamaan hyvin pitkälle päätöslauselmaehdotuksiaan, joista näytti tulevan poliittista erimielisyyttä. 
Muutaman kerran keskustelussa leimahti esiin Israelin ja arabimaiden välinen kiista. $\mathrm{Pu}$ heenjohtaja pystyi voimakkain ottein joka kerta lopettamaan kiistan melko lyhyeen.

Myös Pohjoismaat olivat korostetun varovaisia kannanotoissaan. Niinpä Suomen ulkoasiainministeriönkin taholta suhtauduttiin varauksin valmisteluvaiheessa rauhankasvatuksen korostamiseen Suomen päätöslauselmaluonnoksessa, koska pelättiin asialla olevan poliittista painolastia. Vielä selvemmin tämäntapaiseen esitykseen toivat kielteisen kantansa esiin muiden Pohjoismaiden ulkoasiainministeriöiden edustajat. Suomen valtuuskunta luopuikin tämän todettuaan alkuperäisestä rauhankasvatusta painottavasta päätöslauselmaehdotuksestaan.

Vaikka konferenssia sanottiinkin yleispolitiikan kauttaaltaan sävyttämäksi ja vaikka se pidettiin eräänlaisessa kriisitilanteessa, sen ei loppujen lopuksi neuvottelujen jälkeen tarvinnut äänestää varsinaisesti mistään poliittisesti arkaluontoisesta asiasta.

Toisaalta voi myös todeta, että voimakas pyrkimys kaikkien mahdollisten ristiriitoja aiheuttavien ja taloudellisia resursseja vaativien ehdotusten välttämiseen aiheutti sen, että kovin paljon uutta ja aikuiskoulutusta erityisesti kehittyneissä maissa eteenpäinvievää ei hyväksyttyihin suosituksiin sisälly, vaikka aikuiskasvatuksen merkitys UNESCOn ohjelmissa yleisesti puheenvuoroissa korostuikin. Kannanottojen liiallista varovaisuutta puheenvuoroissa erityisesti kehitysmaiden taholta arvosteltiinkin. Yleensä kaikki uutta ja samalla uusia resursseja vaativat suositukset kohdistettiin jäsenmaille, eikä UNESCOlle tai sitten niiden alkuun liitettiin maininta "käytettävissä olevien voimavarojen rajoissa" tms. Konferenssin menettelytavoista, organisaation eri osien toimivaltuuksista ja koordinoinnista oli koko ajan epäselvyyttä. Tämä näkyi erityisesti suhtautumisesta luonnosteluryhmän työhön.

\section{Plenum-työskentely}

Konferenssi päätti käsitellä plenumissa (yleisistunnossa) esityslistan seuraavat asiakohdat: "Developments in adult education, considered particularly as the extension of literacy activities, since the Tokyo Conference (1972) and the adoption of the Recommendation on the Development of Adult Education (Nairobi, 1976)", "'The development of adult education as an essential prerequisite for lifelong education and an important factor in the democratization of edu- cation: trends and prospects" ja "Measures to improve international and regional co-operation with a view to the advancement of adult education".

Plenum-istuntoja oli kaikkiaan yhdeksän. Ensimmäisessä vaiheessa lähes kaikki osanottajatahot pitivät yleispuheenvuoron, jossa todettiin kunkin maan aikuiskoulutuksen kehitys ja esitettiin toivomuksia konferenssin tulosten suhteen.

Kehitys näyttää edenneen nopeasti kaikkialla viime vuosikymmenen aikana. Useissa maissa oli aikuiskoulutuksen asemaa vahvistettu joko kokonaislainsäädännöllä tai Suomen valtioneuvoston periaatepäätöksen kaltaisella virallisella kannanotolla. Aikuiskoulutus nähdään yleisesti koulutusjärjestelmän osana ja sen yhteyksiä koulumaailmaan korostetaan. Elinikäinen kasvatus näyttää vähitellen tulevan kansainvälisesti yleisesti hyväksytyksi koulutuksen kehittämisen peruslinjaksi. Tässä mielessä monissa puheenvuoroissa korostettiin muodollisen ja vapaamuotoisen oppimisen suhteita ja yhteyksien tarvetta. Hyvin voimakkaasti puhuttiin kansalaisjärjestöjen (nongovernmental organizations) merkityksestä aikuiskasvatuksessa nyt ja tulevaisuudessa.

Maailmanlaajuisiin työllisyysongelmiin nähtiin aikuiskoulutuksella olevan myös erityissuhteet. Edelleen oli kuitenkin huomattavissa UNESCOn selvä suuntautuminen humanismin perinteiden mukaisesti pääasiassa kulttuuripainotteiseen ja ihmisen persoonallisuuden kaikinpuoliseen henkiseen kehittämiseen enemmän kuin ammatilliseen, työelämään liittyvään koulutukseen.

Puheenvuoroissa heijastuivat selvästi UNESCOn taloudelliset ongelmat. Useissa niistä painotettiin voimakkaasti UNESCOn aikuiskoulutusohjelmienkin priorisoimistarvetta eri kategorioihin. Priorisoituna alueena haluttiin nähdä ehkä ennen kaikkea luku- ja kirjoitustaito-ohjelmat. Sen lisäksi korostettiin naisten aseman parantamiseen tähtääviä ohjelmia, kasvatuksen demokratisointiin pyrkiviä toimia, siirtolaiskoulutusta, rauhankasvatusta ja uusiutuvan teknologian haasteisiin vastaavaa koulutusta.

Myös muut Pohjoismaat Suomea lukuunottamatta korostivat pääpuheenvuorossaan UNESCOn aikuiskaśvatusohjelmien priorisoinnin tärkeyttä.

Aikuiskouluttajien koulutus näyttää olevan maailmanlaajuinen ongelma riippumatta aikuiskoulutuksen kehitysasteesta. Kaikkialla on puutetta nimenomaan aikuiskoulutukseen koulutetuista opettajista. Tähän ongelmaan 
nähtiin toisaalta olevan osittain ratkaisuna opetusteknologian nopea kehitys. Aivan erityisesti korostettiin etäopetuksen mahdollisuuksia tässä suhteessa.

Kolmannen maailman ongelmat luonnollisesti korostuivat keskusteluissa. Sen rinnalle oli kuitenkin noussut uusi käsite "neljäs maailma", jolla tarkoitettiin usein hyvinvointiyhteiskuntien rinnalle ja sisälle muodostuvia huonompiosaisuuden kierteeseen joutuneita väestöryhmiä, jotka vieraantuneita ovat hyvin vaikeita tavoitettavia millään järjestäytyneen yhteiskunnan keinoilla. Kaksi muuta erityisryhmää, joihin aikuiskasvatuksen huomio on korostetusti kohdistumassa, on toisaalta eläkeikäisten suureneva joukko, toisaalta nuoret koulunkäyntinsä lopettaneet aikuiset.

Hyvin yleisesti korostettiin kansainvälisen ja alueettaisen informaation ja yhteistyön lisäämisen tärkeyttä aikuiskasvatuksen eri sektoreilla. Informaation lisäämiseksi ehdotettiin jatkuvasti täydennettävien tietopankkien perustamista. Samaten tahdottiin lisätä tutkimuksen ja erityisesti vertailevan tutkimuksen osuutta aikuiskoulutuksen kansainvälisissä yhteyksissä. Tämän mahdollistamiseksi nähtiin ensimmäisen vaiheen tehtäväksi yhteisen käsitteistön luominen, tietojen keruun järjestelmien kehittäminen ja tilastoinnin yhtenäistäminen.

Monet puhujat odottivat UNESCOn auttavan konkreettisesti mm. aikuiskasvatuksessa tarvittavan oppimateriaalin tuottamisessa ja aikuiskasvattajien koulutuksessa. Aikuiskasvatuksen käytännössä yleensä luotettiin enemmän alueelliseen kuin maailmanlaajuiseen yhteistoimintaan.

Pääjohtaja M'Bow päätti konferenssin kertaamalla sen päätapahtumat ja esittäen näkemyksensä sen kauaskantoisesta merkityksestä.

\section{Komissio I}

Komissio I:n työhön osallistuivat Olavi Alkio, Kari Kinnunen, Liekki Lehtisalo ja Kaisa Savolainen. Suomen puheenvuoron pitivät Lehtisalo ja Kinnunen.

Komissio kokoontui kuuteen työistuntoon. Komission käymä keskustelu käsitteli työjärjestyksen kohtaa 8. "The Contribution which Adult Education can make to the Development of Active Participation in Economic, Social and Cultural Life and to the Solution of some of the Major Problems of the Contemporary World"'.

Keskusteluun otti osaa 51 maan edustajat ja tämän lisäksi myös tarkkailijoita: hallituksen välisistä organisaatioista yksi, ei-hallituksen välisistä organisaatioista yhdeksän sekä ei-jäsenvaltioiden edustajista yksi. Lukutaitokampanja korostui eniten keskustelussa. Hyvin voimakkaasti painottui ammatillinen aikuiskoulutus, jossa erityishuomio kohdistettiin teknologisen muutoksen aiheuttamiin vaatimuksiin. Myös aikuiskoulutuksen rooli rauhan ja kansainvälisen yhteisymmärryksen edistämisessä tuli esiin, joskin jonkinasteista varauksellisuutta tähän asiaan esiintyi erityisesti länsiryhmän taholta. Naisten erityisasema aikuiskoulutuksen keskeisenä kohderyhmänä painottui keskustelussa erittäin voimakkaasti.

Kansainvälisen yhteistyön kehittämiseen suhtauduttiin eräin osin varauksellisesti, mitä perusteltiin järjestön nykyisellä taloudellisella tilanteella. Sitä vastoin painotettiin yhteistoiminnan edelleen kehittämistä lähinnä edellä mainituilla keskeisillä aikuiskoulutuksen osaalueilla.

\section{Komissio II}

Komissio II:n työhön osallistuivat Eeva Hippula ja Singa Sandelin. Suomen puheenvuoron esitti Singa Sandelin.

Komissio kokoontui kahdeksaan työistuntoon. Sille jätettiin määräaikaan mennessä 26 suositusta hyväksyttäväksi.

Konferenssin päätöksiä valmisteleva "drafting group" yhteensovitti esitetyistä suosituksista seuraavat neljä:

1. Adult Education Policies

2. Research, Studies, Evolution and Information

3. Planning, Finance, Consultation and Coordination

4. Status and Training of Adult Education Personnel

Komissio katsoi yksimielisesti, että suositusten yhteensovitettu muoto oli liian monisanainen, epätarkka ja jäsentymätön ja päätti lähettää ehdotukset takaisin "drafting group"'iin tiivistämistä varten, sekä sen jälkeen plenumkäsittelyyn.

Komission raportoijan raportti hyväksyttiin pienin lisäyksin sekä lähinnä sanavalintoja koskevin muutoksin.

Muiden pohjoismaiden puheenvuorot käsittelivät:

Tanska - UNESCOn kysely, vaikka se on johtanutkin erittäin kiinnostavaan raporttiin, ei valottanut niitä vaikeuksia ja niitä vastarinnan muotoja, joita aikuiskoulutus eri maissa saattaa kohdata. Tieto myös näistä olisi arvokasta kaikille aikuiskoulutuksen alueella työskenteleville.

Ruotsi - Lyhyessä puheenvuorossaan Ruotsin 
edustaja korosti tässäkin yhteydessä keskittämisen tärkeyttä UNESCOn toiminnassa aikuiskoulutuksen alueella.

\section{Pohjoismainen yhteistyö}

\section{Työskentely}

Pohjoismaiset valtuuskunnat kokoontuivat konferenssin aikana joka päivä. Puheenjohtajana toimi Ruotsi, koska heidän valtuuskuntansa johtajana oli opetusministeri. Myös Norjan valtuuskunnan johtajana oli opetusministeri.

Päätöslauselmia valmisteltiin lisäksi pienemmissä yhteispohjoismaisissa työryhmissä.

Pohjoismailla ei Suomea lukuunottamatta ollut mitään etukäteen valmisteltuja esityksiä konferenssia varten. Ainoastaan ministerien puheista oli luonnokset. Suomella oli suositusesitys kansainvälisyyskasvatuksesta. Lisäksi Suomen valtuuskunta valmisteli suositusesityksen aikuisten ammatillisesta koulutuksesta, joka sisälsi myös tietotekniikasta johtuvat koulutustarpeet aikuiskoulutukselle.

\section{Päätöslauselmat}

Pohjoismaat eivät yhtyneet Suomen suositusehdotukseen kansainvälisyyskasvatuksesta.

Australian edustaja oli kysynyt Suomen valtuuskunnalta mahdollista suositusluonnosta kansainvälisyyskasvatuksesta. Nähtyään luonnoksen Australia ilmoitti olevansa halukas tukemaan sitä ja ilmoitti, että mahdollisesti myös Uusi Seelanti voi olla siitä kiinnostunut.

Ulkoministeriön ohjeiden mukaan Suomi ei kuitenkaan lähtenyt esittämään suositusluonnosta konferenssille ilman Pohjoismaiden tukea.

Myös Saksan liittotasavallalta oli tiedusteltu kantaa suosituksen tukemiseen siinä tapauksessa, että Suomi päättäisi sen esittää. Maan edustaja ilmoittikin valtuuskunnassa käymiensä keskustelujen perusteella voivansa tukea päätöslauselmaa.

Norjan ja Tanskan valtuuskuntien järjestöjen edustajat olisivat mielellään nähneet, että Suomen päätöslauselma kansainvälisyyskasvatuksesta olisi voitu esittää yhteispohjoismaisena.

\section{Yhteispohjoismainen päätöslauselma}

Keskusteluissa todettiin, että Pohjoismaat ovat aina painottaneet UNESCOssa aikuiskas- vatuksen merkitystä järjestön toiminnassa. Tästä syystä päädyttiin siihen, että tehdään yhteispohjoismainen päätöslauselma, jossa kuitenkin korostetaan lähinnä toiminnan keskittämistä. Tähän yhteiseen päätöslauselmaan Norja oli valmis hyväksymään kansainvälisyyskasvatusnäkökulman seurauksena aikuiskasvatuksen kehittämisestä johdanto-osaan ja tähän päätöslauselmaan tuli mukaan myös Suomen toisesta suositusluonnoksesta ammatillista koulutusta koskeva osuus. Suositusluonnoksessa korostettiin keskittämistä aikuiskoulutuksen painopistealueille: lukutaitoon, naisten koulutukseen ja ammatilliseen aikuiskoulutukseen.

Keskittämistä korostava päätöslauselma oli ainoa Pohjoismaiden esittämä päätöslauselma konferenssille.

Tämän lisäksi Norjan valtuuskunta valmisteli suositusesityksen järjestöjen roolista aikuiskasvatuksessa. Tämän valtuuskunta teki aivan ilmeisesti oman valtuuskuntansa järjestöjäsenten toivomuksesta. Työryhmässä suositusta korjailtiin ja päästiinkin pitkälle yhteisymmärrykseen, mutta aivan ilmeistä oli, että enempää Norja, Ruotsi kuin Tanskakaan eivät todellisuudessa halunneet saada aikaan päätöslauselmaa tästä asiasta. Loppujen lopuksi se kaatui siihen, että Tanska totesi jo muilta osin yhteisymmärrykseen päätyneestä päätöslauselmasta, että se ei voinut hyväksyä kohtaa, jossa järjestöjen kehittämistä esitettiin julkisen aikuiskasvatuksjärjestelmän ohella. Tämä johtui siitä, että Tanskassa kaikki aikuiskasvatus on täysin vapaata ilman julkista järjestelmää.

Työryhmissä, joissa päätöslauselmia valmisteltiin, korostui selvästi ulkoministeriöitten rooli, samoin kuin muissakin kokouksen kannanottojen valmisteluissa.

\section{Yhteenveto}

Yleisesti ottaen pohjoismainen yhteistyö konferenssin aikana olì varsin tiivistä ja esiintyminen ulospäin oli yhtenäistä siitä huolimatta, että selvästi esiintyi näkemyseroja $\mathrm{mm}$. kansainvälisyyskasvatuksen tärkeydestä. Tämä oli vielä viime kesäkuussa pohjoismaisten UNESCO-toimikuntien yhteisesti sopima painopistealue. Kun Suomen käyttämissä puheenvuoroissa ei ollut korostettu ohjelman keskittämistarvetta, käytti Suomen edustaja loppuistunnossa puheenvuoron kaikkien viiden Pohjoismaan puolesta todeten myös aikuiskoulutusohjelman toteuttamisessa tarpeen keskittää se sellaisille alueille, jotka ovat kaikkein tärkeimpiä. 


\section{Suositukset}

Suositusluonnoksia konferenssille esitettiin 65. Vasta kuudentena konferenssipäivänä asetettiin ns. luonnosteluryhmä (drafting group) sovittelemaan lähellä toisiaan olevia suositusehdotuksia yhteen ja muokkaamaan niitä yhtenäiseen muotoon. Luonnosteluryhmän puheenjohtajana toimi Tanskan Hanne Søndergaard, joka saikin toiminnastaan yleisesti kiitosta. Luonnosteluryhmä joutui loppuvaiheessa työskentelemään korkeapaineessa ajan niukkuuden takia. Siihen katsoen työ oli erinomaista, eikä plenum-käsittelyssä enää mitään erityisen suuria muutoksia esitettyihin suosituksiin ehdotettukaan.

Suurimmat ongelmat nousivat esiin toisaalta erään Neuvostoliiton laatiman rauhan- ja aseidenriisuntakasvatusta koskevan ehdotuksen osalta ja toisaalta miehitettyjen arabialueiden aikuiskoulutusta koskevan suositusehdotuksen osaita. Näiden kummankin katsottiin olevan sillä tavalla poliittisesti latautuneita, ettei niitä voitu hyväksyä esitetyssä muodossa.

Neuvottelujen jälkeen Neuvostoliitto suostui vetämään oman suosituksensa pois käsittelystä ja arabimaat hyväksyivät miehitettyjen arabialueiden osalta esitetyn kompromissiesityksen. Näin ollen ei näistäkään ehdotuksista jouduttu äänestämään.

Luonnosteluryhmä yhdisteli esitetyt lukuisat suositukset yhdeksäksi suureksi ja osittain melko moniaineksiseksi suosituskokonaisuudeksi!

1. aikuiskasvatuksen päämäärät ja aikuiskasvatuspolitiikka

2. erityisryhmien tarpeet: naiset, vähemmistöt, nuoriso, vanhenevat, vammaiset

3. aikuiskasvatuksen viralliset ja vapaat osaalueet

4. aikuiskasvatuksen teknologia

5. aikuiskasvattajien koulutus

6. luku- ja kirjoitustaito

7. kansainvälinen yhteistyö

8. kehitys, tutkimus, suunnittelu, arviointi

9. tiedottaminen.

Suositusten lisäksi oli laajalla pohjalla laadittu konferenssin hyväksyttäväksi julistusluonnos "The Right to Learn". Vaikka sen sisältöön ei ollutkaan mitään huomauttamista, tuli sen hyväksyminen lopuksi ongelmalliseksi, kun allekirjoittajana esiintyi myös Israel. Arabivaltioiden edustajat kävivät tähän vedoten yksi toisensa jälkeen vetäytymässä allekirjoittajien joukosta pois. Puheenjohtaja Mutumbuka laukaisi tilanteen ottamalla koko aloit- teen nimiinsä, jolloin julistus voitiin yksimielisesti hyväksyä.

Julistuksen alkuosa:

Oikeus oppia on:

oikeus lukea ja kirjoittaa,

oikeus kysellä ja analysoida,

oikeus mielikuvitukseen ja luovuuteen,

oikeus tulkita omaa maailmaansa ja kir-

joittaa historiaa,

oikeus päästä koulutukseen,

— oikeus kehittää yksilöllisiä ja kollektiivisia taitoja.

Pariisin aikuiskasvatuskonferenssi vahvistaa uudelleen tämän oikeuden merkityksen.

Oikeus oppia ei ole sellaista kulttuuriylellisyyttä, mikä voidaan säästää tulevaisuuteen.

Tämä ei ole sellainen oikeus mikä voidaan toteuttaa vasta sen jälkeen kun eloonjäämisen ongelma on ratkaistu.

Se ei ole myöskään seuraava askel mikä otetaan perustarpeiden tyydyttämisen jälkeen.

Oikeus oppia on välttämätön ihmiskunnan henkiinjäämisen keino.

Jos halutaan maailman kansojen tulevan omavaraisiksi ruuan ja muiden inhimillisten tarpeiden tyydyttämisessä, niillä tulee olla oikeus oppia.

Jos miehille ja naisille halutaan turvata parempi terveys, niin heillä tulee olla oikeus oppia.

Jos haluamme välttää sodan, meidän tulee oppia elämään rauhassa ja ymmärtämään toinen toisiamme.

"Oppia" on avainsana.

Ei voi olla inhimillistä kehitystä ilman oikeutta oppia.

Ilman oikeutta oppia ei maatalous eikä teollisuus voi kehittyä, samoin eivät voi terveydenhoito-olot eivätkä elinolosuhteet parantua.

Ilman tätä oikeutta eivät kaupunkiemme eikä kyliemme työläisten elintaso voi parantua.

Ihmiskunnan polttavien ongelmien ratkaisemisessa oikeus oppia on eräs parhaista keinoista.

\section{Suomen valtuuskunnan rooli}

Aikuiskasvatus on alue, jolla Suomi edelleen voi osoittaa olevansa ainakin teorian ja suunnittelun kehittelyn kärkipaikoilla koko maailmaa ajatellen.

Kansainvälisesti kiristyneessä ilmapiirissä korostuu myös Suomen kaltaisten puolueettomien maiden rooli mahdollisena kompromissintekijänä. 
On kuitenkin luonnollista, että yhden valtuuskunnan, ja varsinkin suhteellisen pienen maan valtuuskunnan rooli jää suuressa maailmankonferenssissa melko näkymättömäksi. Paljon voidaan kuitenkin tehdä etukäteisvalmistelulla.

Suomen valtuuskunta valmisteli ennen matkaan lähtöä maan pääpuheenvuoron lisäksi lähes jokaiselle valtuuskunnan jäsenelle puheenvuoron esityslistalla olevista teemoista. Näitä muokattiin vielä perillä keskustelun etenemisen mukaisesti. Samaten valtuuskunta valmisteli myös yhden suositusehdotuksen. Kun tämä rauhankasvatuksen tärkeyttä korostava ehdotus ei saavuttanut muiden pohjoismaiden valtuuskuntien hyväksymistä ja kun osoittautui, että yksikään muu Pohjoismaa ei ollut valmistanut suositusehdotusta, Suomen valtuuskunta valmisteli uuden, ammatillisen aikuiskoulutuksen merkitystä korostavan päätöslauselmaehdotuksen. Loppujen lopuksi päädyttiin asetetun yhteispohjoismaisen työryhmän valmistelun perusteella esittämään yhteistä päätöslauselmaa, johon oli sisällytetty aineksia näistä kummastakin Suomen valmistelemasta ehdotuksesta. Osia näin valmistellusta ehdotuksesta saatiinkin sisällytetyksi konferenssin hyväksymiin suosituksiin.

Suomen pääpuheenvuorossa selostettiin lyhyesti kehitystä edellisen maailmankonferens- sin jälkeen ja kuvattiin Suomen aikuiskoulutuksen suunnittelua ja periaatteita, joille se rakentuu.

Yleensä Suomen valtuuskunta oli ulkoasiainministeriön ohjeiden mukaisesti korostetun varovainen kannanotoissaan. Se ei esimerkiksi allekirjoittanut minkään muun maan suositusluonnoksia (kuten eivät tehneet muutkaan Pohjoismaat).

Suomen edustaja (lähetystöneuvos Iivo Salmi) toimi konferenssin aikana vaaliryhmä I:n (WEO) puheenjohtajana. Etukäteisvalmisteluissa päädyttiin esittämään muille Pohjoismaille, että ne tukisivat Suomen pyrkimystä saada ehdokkaansa vähintään mahdollisesti asetettavien komissioiden puheenjohtajistoon tai raportoijaksi. Tämä onnistuikin niin, että toimistopäällikkö Kaisa Savolainen valittiin komissio I:n varapuheenjohtajaksi.

Kummassakin komissiossa Suomen edustajat käyttivät puheenvuoron. Erityisesti komissio II:n tutkimusta koskevaan osaan saatiinkin Singa Sandelinin esityksestä suhteellisen suora lainaus. Koska Suomen edustaja toimi vaaliryhmä I:n puheenjohtajana, piti valtuuskunnan johtaja tavan mukaan konferenssin lopussa puheenvuoron, jossa kiitettiin konferenssin onnistumiseen vaikuttaneita ja aivan erityisesti luonnosteluryhmää ja sen puheenjohtajaa sekä koko konferenssin puheenjohtajaa. 